\title{
PUBLIC HEALTH REHABILITION AFTER ACUTE MYOCARDIAL INFARCTION: A RANDOMIZED CONTROLLED STUDY
}

\author{
${ }^{1}$ D. G. Zhamankulova, ${ }^{1}$ L. M. Zhamaliyeva, ${ }^{1}$ G. L. Kurmanalina, ${ }^{1}$ Z. Tanbetova, ${ }^{1,2,3,4}$ A. M. Grjibovski \\ ${ }^{1}$ West Kazakhstan Marat Ospanov Medical University, Aktobe, Kazakhstan; \\ ${ }^{2}$ Northern State Medical University, Arkhangelsk, Russia; ${ }^{3}$ North-Eastern Federal University, Yakutsk, Russia; \\ ${ }^{4} \mathrm{Al}-$ Farabi Kazakh National University, Almaty, Kazakhstan
}

Background: Cardiovascular diseases (CVD) are the main causes of death worldwide. The incidence of and mortality from CVD in Kazakhstan is greater than in most neighboring countries warranting urgent public health measures related to both primary, secondary and tertiary prevention.

Aims: To assess whether a newly developed 6-months public health rehabilitation program for patients with acute myocardial infarction (AMI) with home visits performed by physician assistants is superior to the standard rehabilitation of these patients in Western Kazakhstan.

Methods: A randomized controlled study. A total of 75 AMI patients were enrolled after discharge form the hospital and 72 completed the trial. The control group $(n=34)$ participated in the standard rehabilitation program while the intervention group $(n=38)$ underwent and experimental rehabilitation program with home visits in addition to the standard program. Body mass index, waist circumference, blood pressure, heart rate, blood lipids, smoking and compliance to the treatment were assessed at the enrollment and after 6 months of the follow-up. Differences between the changes in the intervention and in the control group were compared using Mann-Whitney tests.

Results: The experimental program was superior to the standard program in reducing systolic- $(-22.5 \mathrm{vs} .-2.9 \mathrm{~mm} \mathrm{Hg}, \mathrm{p}<0.004)$ and diastolic $(-6.3$ vs. $-0.6 \mathrm{~mm} \mathrm{Hg}, \mathrm{p}=0.032)$ blood pressure, body mass index $\left(-0.99\right.$ vs. $\left.0.53 \mathrm{~kg} / \mathrm{m}^{2}, \mathrm{p}<0.001\right)$, waist circumference $(-3.0$ vs. $1.7 \mathrm{~cm}, \mathrm{p}<0.001)$ and the number of smoked cigarettes $(-12$ vs. $-3, p=0.002)$. Blood lipid profiles improved in both groups. Although slightly more pronounced changes were observed in the intervention group, the differences did not reach the level of statistical significance.

Conclusions: The program was more effective on blood pressure, smoking and obesity-related indicators than the standard rehabilitation. Larger studies are warranted to corroborate our findings prior to implementation of the program in practice.

Key words: acute myocardial infarction, rehabilitation, primary care, Kazakhstan, physician assistants

УДК [616-006:614.1] (470.61)

DOI: $10.33396 / 1728-0869-2021-8-57-64$

\section{АМБУЛАТОРНАЯ РЕАБИЛИТАЦИЯ ПОСЛЕ ОСТРОГО ИНФАРКТА МИОКАРДА: РАНДОМИЗИРОВАННОЕ КОНТРОЛИРУЕМОЕ ИСПЫТАНИЕ}

\author{
() 2021 г. ${ }^{1}$ Д. Г. Жаманкулова, ${ }^{1}$ Л. М. Жамалиева, ${ }^{1}$ Г. Л. Курманалина, ${ }^{13 .}$ Танбетова, ${ }^{1,2,3,4}{ }^{4}$. М. Гржибовский \\ 1Западно-Казахстанский медицинский университет имени Марата Оспанова, Актобе, Казахстан; \\ ²Северный государственный медицинский университет, г. Архангельск, Россия; \\ ${ }^{3}$ Северо-Восточный федеральный университет имени М. К. Аммосова, г. Якутск, Россия; \\ «Казахский национальный университет имени Аль-Фараби, г. Алматы, Казахстан
}

\begin{abstract}
Актуальность: Сердечно-сосудистые заболевания (ССЗ) являются основными причинами смерти во всем мире. Заболеваемость и смертность по причине СС3 в Казахстане выше, чем в большинстве соседних стран, что требует неотложных мер общественного здравоохранения, связанных как с первичной, вторичной, так и с третичной профилактикой.

Цели: Оценить, превосходит ли недавно разработанная 6-месячная программа реабилитации пациентов с острым инфарктом миокарда (ОИМ) на дому с помощью врачей стандартную реабилитацию пациентов с ОИМ в Западном Казахстане.

Методы: В рандомизированное контролируемое исследование были включены 75 пациентов с ОИМ после выписки из больницы, и 72 пациента завершили исследование. Контрольная группа ( $n=34)$ участвовала в стандартной программе реабилитации, группа вмешательства $(\mathrm{n}=38)$ прошла экспериментальную программу реабилитации с посещениями на дому в дополнение к стандартной программе. Индекс массы тела, окружность талии, артериальное давление, частота сердечных сокращений, липиды крови, курение и соблюдение режима лечения оценивались при включении и через 6 месяцев наблюдения. Различия между изменениями в группе вмешательства и в контрольной группе сравнивали с помощью тестов Манна - Уитни.

Результаты: Экспериментальная программа превосходила стандартную по снижению систолического (-22,5 против $-2,9$ мм рт. ст., $p<0,004)$ и диастолического $(-6,3$ против $-0,6$ мм рт. ст., $p=0.032)$ артериального давления, индекса массы

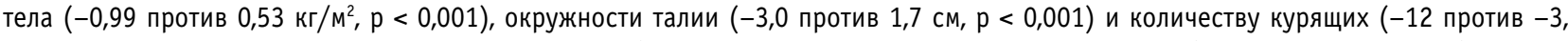
$\mathrm{p}=0,002)$. Липидный профиль крови улучшился в обеих группах. Хотя в группе вмешательства наблюдались несколько более выраженные изменения, различия не достигли уровня статистической значимости.

Выводы: Программа оказалась более эффективной по показателям артериального давления, курения и ожирения, чем стандартная реабилитация. Необходимы более масштабные исследования для подтверждения наших выводов до реализации программы на практике.
\end{abstract}

Ключевые слова: острый инфаркт миокарда, реабилитация, первичная помощь, Казахстан, помощники врачей 


\section{For citing:}

Zhamankulova D. G., Zhamaliyeva L. M., Kurmanalina G. L., Tanbetova Z., Grjibovski A. M. Public Health Rehabilition after Acute Myocardial Infarction: a Randomized Controlled Study. Ekologiya cheloveka (Human Ecology). 2021, 8, pp. 57-64.

\section{Библиографическая ссылка:}

Жаманкулова Д. Г., Жамалиева Л. М., Курманалина Г. Л., Танбетова 3., Гржибовский А. М. Амбулаторная реабилитация после острого инфаркта миокарда: рандомизированное контролируемое испытание // Экология человека. 2021. № 8. С. 57-64.

\section{Introduction}

Cardiovascular diseases (CVD) are the main causes of death worldwide representing a substantial threat to sustainable development of mankind [14]. According to the World Health Organization (WHO), the number of deaths from CVD was 17.9 million in 2016 accounting for $31 \%$ of all deaths in the world. Eighty-five percent of them were attributed to heart attack or stroke. Ischemic heart disease (IHD) is a significant cause of healthy life loss in all countries [22, 31], but death rates from IHD considerably vary between countries [17]. Of 17 million premature deaths from non-communicable diseases $82 \%$ occurred in low- and middle-income countries in 2015. Age standardized mortality from IHD in former Soviet republics is substantially higher than in most other countries. For example, in Ukraine and Kazakhstan, the mortality from IHD was 324 and 97 per 100000 respectively while in the USA and the UK the corresponding numbers were 60 and 46 per 100000 [28]. Kazakhstani authors, however, have reported that the mortality from CVD was 219 per 100000 in 2015 with IHD and cerebrovascular causes being the main killers causing $47.7 \%$ and $36.4 \%$ of deaths, respectively $[10,19,30]$.

The incidence of CVD in Kazakhstan increased from 2086.7 per 100000 in 2010 to 2394.7 per 100000 in 2014. Acute myocardial infarction (AMI) was among the components of CVD showing the greatest increase in incidence in Kazakhstan. Lethality of AMI in Kazakhstan was $55.7 \%$ compared to $54.3 \%$ in Ukraine, $44.0 \%$ in Russia, $61.6 \%$ in Armenia [6].

Rehabilitation of cardiac patients in primary healthcare is the most important evidence-based intervention to reduce the risk of repeated $\mathrm{MI}$, hospitalization and allcause mortality after AMI [23]. It has also been reported that cardiorehabilitation in IHD patients increases physical load tolerance, reduces the risk of hospitalization and improves the quality of life [27]. Rehabilitation after AMI includes lifestyle changes, physical exercise, selfmanagement and psychosocial interventions. Most of the CVDs are potentially preventable through lifestyle changes such as smoking cessation, reducing hazardous alcohol consumption, body weight control, healthy diet and health-enhancing physical activity. Based on the study that included 18809 AMI patients from 41 countries, the Australian authors have reported that the patients who kept smoking and had not changed their diet and physical activity after AMI were 3.8 times more likely to have a repeated MI, stroke or death compared to their non-smoking counterparts who changed diet and physical activity [13]. In a meta-analysis of 34 randomized controlled studies, cardiorehabilitation was associated with lower odds for repeated $\mathrm{AMI}(\mathrm{OR}=0.53$, 95\% CI: 0.38-0.76), cardiac death $(\mathrm{OR}=0.64$,
$95 \%$ CI: 0.46-0.88) and all-cause mortality $(\mathrm{OR}=0.74$, $95 \%$ CI: 0.58-0.95). Moreover, cardiorehabilitation had positive effects on traditional risk factors for CVD such as smoking, arterial hypertension, body weight and dyslipidemia [25]. Despite the substantial body of international evidence on the effectiveness of cardiorehabilitation in AMI patients, the proportion of patients participating in rehabilitation programs varies between $25 \%$ and $35 \%$ in the Western countries [34]. Although there was no scientific assessment of the participation of AMI patients in rehabilitation programs in Kazakhstan, it has been reported that most of Kazakhstani patients keep smoking, practice unhealthy diets and low physical activity that reduces their survival after discharge [24].

Limited use evidence-based effective low cost cardiorehabilitation programs suggests the presense of barriers for their implementation. Clinical protocol for outpatient rehabilitation of AMI patients in Kazakhstan represents a paternalistic approach with no active participation of the patients and does not include contemporary evidence-based practices. Combined with the lack of multidisciplinary teams for successful cardiorehabilitation, the situation has a substantial potential for improvement in Kazakhstan. At the same time, it has been reported that nurses and physician assistants are capable to run effective secondary prevention programs [9, 20].

Medical students and interns represent an active part of the medical resources that can provide education on healthy nutrition, physical activity, assist to quit smoking, contribute to better compliance to outpatient treatment and provide other assistance to general practitioners or cardiologists in outpatient rehabilitation of AMI patients. Although these practices sporadically appear in Kazakhstan, there has been no scientific evaluation of the effectiveness of these activities.

We developed a public health rehabilitation program for AMI patients run by medical students under supervision of a clinical tutor. This program is incorporated into routine outpatient rehabilitation in policlinics and complements it with home visits and health education.

The aim of the study was to assess the effectiveness of this public health rehabilitation of AMI patients performed by medical students under supervision of a clinician.

\section{Methods}

We performed an open randomized controlled study in Aktobe, Western Kazakhstan. All individuals with verified AMI discharging from the Department of Cardiology at the West Kazakhstan Medical University Centre, Aktobe were invited to participate in the study from 1 April 2019 through 31 September 2019. 
They were informed about the aims of the study and signed an informed consent. If they fulfilled eligibility criteria and signed informed consent, they were randomized into either an experimental or a control group. Randomization was performed using a random numbers generator by a person not related to the study. The participants were not blinded, i.e. they knew which group they belonged to. Patients with conditions that could introduce bias, such as decompensated heart-, kidney- or liver failure, malignant neoplasms cognitive impairments, hearing loss or living in remote areas of the region were excluded.

Baseline examination was performed at the abovementioned department. All patients underwent physical examination and were interviewed. Data on the laboratory- and instrumental tests as well as details on treatment were obtained from medical records.

Patients in the control group underwent rehabilitation according to the National clinical protocol for rehabilitation of patients after AMI including free 10days course of cardiorehabilitation in the municipal rehabilitation center. The standard rehabilitation included registration in the list of patients for long-term follow up, prescription of beta-blockers, angiotensin converting enzyme (ACE) blockers, diuretics, Ca-channels blockers, statins and antiplatelet therapy on indications. The above-mentioned medicines if prescribed are free to AMI patients in Kazakhstan.

Patients in the experimental group in addition to the standard rehabilitation were exposed to a new public health rehabilitation program developed at the West Kazakhstan Medical University. The program was developed and coordinated by clinical lecturers while the main activities - repeated home visits - were carried out by volunteer medical students.

Each visit was planned to last for 1 hour and consisted of 2 parts. The first part consisted of establishment of the contact, a brief assessment of the patient's health status by an interview on complaints and changes since the last visit, measurement of blood pressure, heart rate, body weight and waist circumference. Smokers were asked about the average number of cigarettes smoked per day. The second part of each of the visit was devoted to education, support and motivation according to the scheme presented below.

Visit 1: Patient-oriented education on medications using Calgary-Cambridge method. On obligatory medications after AMI. Barriers for regular intake of prescribed medications were discussed and individual solutions were found in each case to increase compliance. Moreover, the patients were informed about target values of blood pressure, heart rate, cholesterol, LDL and HDL to involve the patients in the monitoring process.

Visit 2: Education on physical activity. First, a 6 -minute walking test was performed to assess the initial level of physical fitness of the patient. Then an optimal for each patient regiment of physical activity was discussed and agreed upon. Individual plans for physical activity for each patient were developed and checked at each subsequent visit.
Visit 3: Education on healthy nutrition. At this visit, current nutritional patterns were discussed and ways to improve it were identified. Education on healthy nutrition based on the European recommendation on the prevention of cardiovascular diseases from 2016 was performed. Individual nutritional plan was developed for each patient.

Visit 4: Guidance on weight reduction and/or quitting smoking. Smoking status and smoking history were assessed. Weight, height, and waist circumference were measured and body mass index was calculated. Motivational interviews on quitting smoking or reducing the number of cigarettes smoked per day as well as on weight reduction when necessary were performed.

Visit 5 and subsequent visits were follow-up visits to keep us with patient's motivation and monitor the issues presented above.

The visits were once a week during the first two months. After that the visits took place every second week. Physician assistants who performed the visits were available by phone any time. The coordinating tutor arranged regular meetings with the assistants and performed the visits together with them when necessary.

The effectiveness of the intervention was assessed using the following measurements: systolic and diastolic blood pressure, heart rate, compliance to medications, total cholesterol, LDL, HDL, creatinine, blood glucose, BMI, waist circumference, smoking as dichotomous variable and the number of cigarettes smoked a day.

The target value for blood pressure was 130/80 mm $\mathrm{Hg}$ according to the ESC/ESH Guidelines for the Management of Arterial Hypertension from 2018 [12]. BMI above $30 \mathrm{~kg} / \mathrm{m}^{2}$ was considered as overweight. Critical waist circumference was $102 \mathrm{~cm}$ for men and $88 \mathrm{~cm}$ for women. The target value for LDL cholesterol was below $1.8 \mathrm{mmol} / \mathrm{l}$ as recommended by the European Cardiological Society 13]. Differences between the values 6 months after- and at the beginning of the trial were calculated for systolic blood pressure, diastolic blood pressure, heart rate, BMI, waist circumference, LDL cholesterol and the number of cigarettes smoked. Differences between the differences were calculated.

Sample size was calculated using WinPepi software with levels of alfa- and beta-errors of $5 \%$ and $20 \%$, respectively using the expected differences which we considered to be clinically important. Numeric variables were presented as medians and interquartile ranges. Categorical variables were presented as absolute numbers and percentages. Continuous variables in independent groups were compared using Mann-Whitney tests. For paired observations we used Wilcoxon tests. Categorical variables were analyzed with Pearson's chi-squared tests and Fischer's exact tests were appropriate. McNemar tests were applied for paired comparisons of dichotomous data. Differences between before-after changes in all studied characteristics were assessed using unpaired t-tests since the differences were normally distributed as was assessed by Shapiro-Wilk tests. In addition to significance testing, we calculated effect sizes for all 
tests performed. For comparisons of the two mean values, we used Cohen d or Glass's Delta when the groups had unequal standard deviations. A value of 0.20 indicates small effect, 0.50 - medium effect and 0.80 strong effect. All differences were considered significant at $p<0.05$. All calculations were performed using IBM SPSS v.25 software.

This study was approved by the local research ethics committee (protocol 4 from 29 January 2018) and financially supported by the internal grant from the West Kazakhstan Marat Ospanov Medical University. The trial was registered at the National Center for Scientific and Technical Expertise of the Republic of Kazakhstan (N 0119PКИ0256).

\section{Results}

Altogether, there were 101 patients eligible for the study during the study period. Of them, 75 participated. Three of them did not finish the study. Two were lost to follow up and one refused after initiation of the study. The final sample consisted of 72 individuals. The flow chart is presented on Figure.

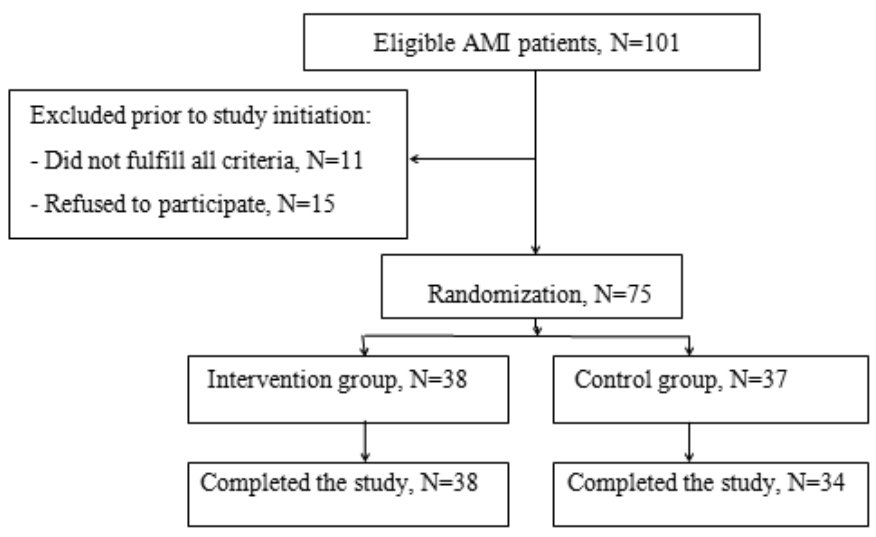

Sampling frame for the randomized controlled trial on the effectiveness of public health rehabilitation of AMI patients in Western Kazakhstan

In Table 1 the main characteristics of the sample are summarized. More than three thirds of the patients were men. The age of the patients ranged from 34 to 81 years. The intervention group and the control group were not significantly different in any of the studied socio-demographic, anamnestic or clinical characteristics (Table 1). Hypertension, smoking, overweight, abnormal values of LDL were highly prevalence in both groups. AMI with a $\mathrm{Q}$-wave was registered in more than a half of the patients. Severity of the AMI and the duration of in-hospital stay were similar in both groups.

Registration of patients for a follow-up after discharge from the hospital in primary health care units was timely in both groups (92\% in the experimental and $82 \%$ in the control group, $p=0.212$ ). The course of inhospital rehabilitation within 6 months after discharge was taken by less than a half of the patients $(26.3 \%$ in the intervention group vs. $41.2 \%$ in the control group, $\mathrm{p}=0.182$ ).
Table 1

Baseline characteristics of the AMI patients at the beginning of the study

\begin{tabular}{|c|c|c|c|}
\hline Characteristic & $\begin{array}{c}\text { Intervention group } \\
\mathrm{N}=38\end{array}$ & $\begin{array}{c}\text { Control group } \\
\mathrm{N}=34\end{array}$ & $\mathrm{P}$ \\
\hline Age, years & $57(51-64)$ & $58.5(54-64)$ & 0.366 \\
\hline Proportion of men, \% & $29(76.3 \%)$ & $28(82.4 \%)$ & 0.529 \\
\hline Body mass index, $\mathrm{kg} / \mathrm{m}^{2}$ & $27.8(25.3-30.9)$ & $26.4(24.3-29.7)$ & 0.415 \\
\hline $\begin{array}{l}\text { Waist circumference, } \\
\mathrm{cm}\end{array}$ & $101.5(94-108)$ & $102(90-108)$ & 0.690 \\
\hline Proportion of smokers & $23(60.5 \%)$ & $17(50 \%)$ & 0.369 \\
\hline $\begin{array}{l}\text { Cigarettes smoked per } \\
\text { day }\end{array}$ & $20(17.5-30)$ & $20(20-20)$ & 0.884 \\
\hline $\begin{array}{l}\text { Systolic blood pressure, } \\
\mathrm{mm} \mathrm{Hg}\end{array}$ & $140(120-150)$ & $137.5(120-150)$ & 0.609 \\
\hline $\begin{array}{l}\text { Diastolic blood } \\
\text { pressure, } \mathrm{mm} \mathrm{Hg}\end{array}$ & $85(80-90)$ & $80(80-90)$ & 0.548 \\
\hline $\begin{array}{l}\text { Heart rate, } \\
\text { beats/min }\end{array}$ & $74(68-80)$ & $79.5(70-80)$ & 0.249 \\
\hline Cholesterol, mmol/1 & $5.2(4.3-5.7)$ & $5.0(4.4-6.6)$ & 0.384 \\
\hline Triglycerides, mmol/1 & $1.2(0.9-1.8)$ & $1.2(0.8-1.7)$ & 0.732 \\
\hline HDL, $\mathrm{mmol} / \mathrm{l}$ & $1.1(0.9-1.3)$ & $1.1(0.8-1.3)$ & 0.897 \\
\hline LDL, mmol/1 & $3.1(2.5-3.8)$ & $3.3(2.5-4.1)$ & 0.354 \\
\hline Glucose, mmol/1 & $7.1(5.8-9.4)$ & $6.5(5.2-7.9)$ & 0.304 \\
\hline Creatinine, micromol/1 & $72.7(66-90.1)$ & $79.5(68-99)$ & 0.449 \\
\hline Grade III hypertension & $25(65.8 \%)$ & $23(67.6 \%)$ & 0.872 \\
\hline Repeated IM & $8(21.1 \%)$ & $10(29.4 \%)$ & 0.413 \\
\hline $\begin{array}{l}\text { AMI with abnormal } \\
\text { Q-wave }\end{array}$ & $23(60.5 \%)$ & $18(52.9 \%)$ & 0.516 \\
\hline Diabetes mellitus & $7(18.4 \%)$ & $6(17.6 \%)$ & 0.932 \\
\hline Killip stage II or III & $6(15.8 \%)$ & $7(20.6 \%)$ & 0.597 \\
\hline Thrombolysis & $6(15.8 \%)$ & $5(14.7 \%)$ & 0.898 \\
\hline C-reactive protein & $3.0(1.2-10.7)$ & $3.4(1.6-14.2)$ & 0.617 \\
\hline Troponin & $1.2(0.4-10)$ & $1.0(0.3-8.6)$ & 0.415 \\
\hline $\begin{array}{l}\text { Duration of in-hospital } \\
\text { stay, days }\end{array}$ & $7(6-9)$ & $7(6-8)$ & 0.770 \\
\hline
\end{tabular}

LDL - low density lipoproteins, HDL - high density lipoproteins.

Six months after the initiation of the intervention we observed significant differences between the groups in systolic blood pressure, diastolic blood pressure, heart rate, LDL and the number of cigarettes smoked per day. By the end of the observation period the target systolic and diastolic blood pressure was achieved in $73.7 \%$ and $34.2 \%$, respectively, in the intervention group while the corresponding proportions in the control group were $35.3 \%$ and $14.7 \%$. The proportion of patients with obesity decreased from $29 \%$ to $21 \%$ in the experimental group in contrast to the increase from $20 \%$ to $27 \%$ in the control group. However, the differences between the groups after six months in average values for BMI and waist circumference did not reach the level of statistical significance. The proportion of smokers decreased in both groups, but the difference between the groups remained non-significant as at the beginning of the trial. At the same time the decrease in the number of cigarettes smoked per day was more pronounced in the intervention group.

Concentrations of total cholesterol and LDL cholesterol significantly decreased in both groups. The proportions of patients reaching the target level of total cholesterol below $4.0 \mathrm{mmol} / 1$ after 6 months were $42 \%$ in the experimental group and $32 \%$ in 
the control group, although the differences were not statistically significant. Thirteen percent of patients in the intervention group reached the target level of LDL cholesterol below $1.8 \mathrm{mmol} / 1$ compared to $12 \%$ in the control group. The level of LDL cholesterol below $2.5 \mathrm{mmol} / \mathrm{l}$ was achieved by $58 \%$ of patients in the experiments group vs. $41 \%$ in the control group.

Table 2 presents the most important findings of this study, namely, the differences between the changes observed in the studied outcomes in the two groups. Significant benefits of the intervention in the experimental group in comparison with the standard rehabilitation in the control group were observed for the body mass index, waist circumference, systolic blood pressure, diastolic blood pressure and the number of cigarettes smoked per day. At the same time, the intervention was not superior to standard rehabilitation in improving the lipid profile or heart rate of the patients. Average BMI decreased by $3.6 \%$ in the experimental group, but increased by $2 \%$ in the control group. Similarly, average waist circumference decreased by $2.9 \%$ in the intervention group, but increased by $1.7 \%$ in the control group. Mean systolic- and diastolic blood pressure decreased by $16 \%$ and $7.4 \%$, respectively, in the experimental group while the corresponding values in the control group were only $2.0 \%$ and $0.8 \%$, respectively. The number of cigarettes smoked per day decreased by 61 $\%$ in the experimental group and by $17 \%$ in the control group. Moreover, our effect size calculations demonstrated high effectiveness of the intervention on controlling blood pressure and smoking. Total cholesterol and LDL cholesterol decreased in both groups, but the changes were not different between the groups. Concentration of HDL cholesterol has not changed in any of the groups. Surprisingly, concentrations of triglycerides significantly increased in both groups, but no difference between the groups was found (Table 2).

Table 3 presents compliance to treatment in both groups at the beginning and after 6 months of the intervention. No differences in the proportions of patients taking the studied medications were observed at the beginning of the study. After 6 months, the proportion of patients using beta-blockers and aspirin was high in both groups, although more patients used aspirin in the intervention groups compared to the control group ( $100 \%$ vs. $88 \%$, $\mathrm{p}=0.029)$. Proportions of patients regularly taking statins (89.5\% vs. $70.6 \%, p=0.043$ ) and ACE inhibitors $(94.7 \%$ vs. $73.5 \%, p=0.012)$ were also greater in the intervention group. Other medications were relatively uncommon in both groups. The most notable reduction in the proportion of patients taking selected medications was observed for statins ( $10.5 \%$ in the experimental- and $24.4 \%$ in the control group) and ACE inhibitors (5.3\% in the intervention- and $20.6 \%$ in the control group). At the same time we observed that more patients started taking aspirin and thiazide diuretics in the experimental group. At the same time Calcium channels blockers were more frequently used in the intervention group. In total, more people were taking antihypertensive medicines after 6 months in the experimental group.

\section{Discussion}

Our main findings suggest that the newly developed program of public health rehabilitation of AMI patients performed by medical students under supervision of a clinical tutor in addition to standard rehabilitation improves control over risk factors for cardiovascular diseases. The program was superior in terms of blood pressure control, body mass index, waist circumference and smoking compared to the standard rehabilitation. Lipid profile improved in both groups, but the effect in the experimental group was not statistically different from that in the control group. Better compliance to treatment was also observed in the experimental group.

Blood pressure control is an important intermediate milestone associated with long-term prognosis. Reduction of blood pressure to the levels below $130 / 80 \mathrm{~mm} \mathrm{Hg}$ is associated with $27 \%$ reduction in all-cause mortality and $25 \%$ cardiovascular mortality [35]. The results we observed in the control group are similar to those observed in a recent Russian study where the target level of blood pressure below 140/90 mm Hg was achieved in only $34.8 \%$ of patients and the level below $130 / 80 \mathrm{Hg}$ was reached in $11.5 \%$ of the patients in standard out-patient conditions [4]. The EUREKA study has reported that the target level of blood pressure was reached in $50 \%$ of patients [11]. In another Russian study (ESSE) the proportion of effective treatment was reported to be $53.5 \%$ among women and $41.4 \%$ among men [2]. In a Dutch study on the effectiveness of

Mean values for the differences between the values after 6 months and at the initiation of the study

Table 2 in the intervention- and the control group

\begin{tabular}{|c|c|c|c|c|}
\hline Changes in: & Intervention group & Control group & $\mathrm{P}$ & Effect size \\
\hline Body mass index, $\mathrm{kg} / \mathrm{m}^{2}$ & $-0.99(-1.4 ;-0.6)$ & $0.53(-0.004 ; 1.06)$ & $<0.001$ & 0.22 \\
\hline Waist circumference, $\mathrm{cm}$ & $-2.98(-3.8 ;-2.2)$ & $1.7(0.6 ; 2.7)$ & $<0.001$ & 0.25 \\
\hline Number of cigarettes a day & $-12.1(-16.3 ;-7.9)$ & $-3.4(-6.8 ; 0.05)$ & 0.002 & 1.00 \\
\hline Systolic blood pressure & $-22.5(-33.2 ;-11.7)$ & $-2.9(-13.7 ; 8.04)$ & 0.004 & 0.80 \\
\hline Diastolic blood pressure & $-6.3(-10.7 ;-1.99)$ & $-0.6(-5.4 ; 4.2)$ & 0.032 & 0.75 \\
\hline Heart rate per minute & $-11.3(-15.5 ;-7.1)$ & $-9.6(-13.6 ;-5.5)$ & 0.550 & 0.61 \\
\hline Cholesterol, mmol/1 & $-1.06(-1.46 ;-0.66)$ & $-0.86(-1.32 ;-0.41)$ & 0.689 & 0.43 \\
\hline Triglycerides, mmol/1 & $0.42(0.28 ; 0.37)$ & $0.24(0.18 ; 0.67)$ & 0.969 & 0.10 \\
\hline $\mathrm{HDL}, \mathrm{mmol} / \mathrm{l}$ & $-0.04(-0.17 ; 0.09)$ & $0.05(-0.08 ; 0.18)$ & 0.703 & 0.28 \\
\hline LDL, mmol/l & $-0.65(-0.95 ;-0.34)$ & $-0.41(-0.82 ;-0.01)$ & 0.229 & 0.44 \\
\hline
\end{tabular}

LDL - low density lipoproteins, HDL - high density lipoproteins. 
Compliance to the use of medications at the beginning of the study and after 6 months

\begin{tabular}{|c|c|c|c|c|c|c|}
\hline \multirow[b]{2}{*}{ Medicine } & \multicolumn{2}{|c|}{ At the enrollment } & \multirow[b]{2}{*}{$\mathrm{P}$} & \multicolumn{2}{|c|}{ After 6 months } & \multirow[b]{2}{*}{$\mathrm{P}$} \\
\hline & $\begin{array}{c}\text { Intervention } \\
\mathrm{N}=38\end{array}$ & $\begin{array}{c}\text { Control } \\
\mathrm{N}=34\end{array}$ & & $\begin{array}{c}\text { Intervention } \\
\mathrm{N}=38\end{array}$ & $\begin{array}{l}\text { Control } \\
\mathrm{N}=34\end{array}$ & \\
\hline Beta blockers & $37(97.4 \%)$ & $34(100 \%)$ & 0.340 & $37(97.4 \%)$ & $31(91.2 \%)$ & 0.252 \\
\hline ACE inhibitors & $38(100 \%)$ & $32(94.1 \%)$ & 0.129 & $36(94.7 \%)$ & $25(73.5 \%)$ & 0.012 \\
\hline Statins & $38(100 \%)$ & $34(100 \%)$ & 1.0 & $34(89.5 \%)$ & $24(70.6 \%)$ & 0.043 \\
\hline Clopidogrel & $31(81.6 \%)$ & $27(79.4 \%)$ & 0.816 & $30(78.9 \%)$ & $23(67.6 \%)$ & 0.277 \\
\hline Ticagrelorum & $6(15.8 \%)$ & $7(20.6 \%)$ & 0.597 & $7(18.4 \%)$ & $4(11.8 \%)$ & 0.433 \\
\hline Aspirin & $37(97.7 \%)$ & $33(97.1 \%)$ & 0.936 & $38(100 \%)$ & $30(88.2 \%)$ & 0.029 \\
\hline CCB & $5(13.2 \%)$ & $4(11.8 \%)$ & 0.858 & $10(26.3 \%)$ & $3(8.8 \%)$ & 0.054 \\
\hline Thiazide diuretics & $1(2.6 \%)$ & $2(5.9 \%)$ & 0.490 & $5(13.2 \%)$ & $0(\%)$ & 0.028 \\
\hline Loop diuretics & $7(18.4 \%)$ & $4(11.8 \%)$ & 0.433 & $5(13.2 \%)$ & $5(14.7 \%)$ & 0.849 \\
\hline Aldosteron antagonists & $10(26.3 \%)$ & $7(20.6 \%)$ & 0.568 & $6(15.8 \%)$ & $4(11.8 \%)$ & 0.622 \\
\hline
\end{tabular}

ACE - Angiotensin converting enzyme; CCB - Calcium channel blockers.

secondary prevention performed by nurses, patients' blood pressure was reduced to the level of below $140 \mathrm{~mm} \mathrm{Hg}$ was reached in $72 \%$ in the experimental- and $65 \%$ in the control group, which is comparable with our findings [20].

According to the European recommendations form 2011 the level of LDL cholesterol should be used as the main indicator while total cholesterol is recommended when analysis of lipid fractions is not possible. Although reduction of LDL cholesterol by each $1 \mathrm{mmol} / \mathrm{l}$ is associated with reduction in cardiovascular mortality by $22 \%$ [5], but recent studies from Russia have reported poor control of dyslipidemia in current out-patient practice [5]. The proportion of patients reaching the level of total cholesterol below $4 \mathrm{mmol} / 1$ varied between $4 \%$ and $13 \%$ and below $4.5 \mathrm{mmol} / \mathrm{l}$ varied between $6 \%$ and $17 \%$ [1]. When special emphasis was given to cholesterol control, the corresponding proportions were $15.8 \%$ and $40 \%$, respectively [7]. Jorstad et al have reported that the level of LDL cholesterol of below $2.5 \mathrm{mmol} / 1$ was reached in $80 \%$ of patients in the group assisted by nurses and $69 \%$ in the control [20]. These findings were reached, in our opinion, because of generally lower levels of cholesterol. In their study, the proportion of patients with LDL cholesterol below $2.5 \mathrm{mmol} / 1$ was $68 \%$ compared with $26 \%$ in our study. A recent cohort study from the UK has shown that the optimal reduction of LDL cholesterol within a 2 -years period is not reached in $51.2 \%$ of patients [8]. Therefore, the observed in our study cholesterol reduction during a 6 -months period can be considered as an effective intervention in Kazakhstani circumstances.

The success of our intervention in terms of good blood pressure control can be at least partly explained by better compliance in the intervention group compared to the control group over the study period. An American study including more than 270 thousand patients has shown that rehabilitation of patients with cardiovascular diseases performed by physician assistants or nurses is effective and is not inferior to rehabilitation managed by medical doctors in terms of compliance to treatment, blood pressure control, physical activity and reduction in blood lipids concentrations [33]. This is in line with our initial hypothesis that trained physician assistants in Kazakhstan can successfully perform rehabilitation of AMI patients.
The RESPONSE study, in which the program of secondary prevention in patients with acute coronary syndrome was coordinated by nurses, has reported the results very similar to ours [20]. However, the RESPONSE study was carried out in secondary or tertiary level institutions by qualified nurses while in our study the main activities were performed by physician assistants (medical students). Our intervention has demonstrated its feasibility and it can be considered as a cost-effective alternative in countries with limited recourses. Moreover, early involvement of the students into clinical practice as physician assistants helps the universities in arranging obligatory practical training for the students with clinical or practice-oriented tutors [21]. Our conclusions are in line with the European recommendations regarding team work of medical doctors, nurses and physician assistants for successful secondary prevention of cardiovascular diseases through lifestyle modifications [15].

It is well-established that abdominal obesity is a significant risk factor for CVD [29]. WHO recommends weight reduction when waist circumference is equal or greater than $102 \mathrm{~cm}$ in men and $88 \mathrm{~cm}$ in women [3]. Waist circumference decreased by $2.9 \mathrm{~cm}$ in the intervention group while it increased by $1.7 \mathrm{~cm}$ in the control group in our study that could be associated with motivational interviews and regular check-ups during home visits in the experimental group. Moreover, the decrease in waist circumference in our experimental group was more than double as great as in the RESPONSE study $(-1.3 \mathrm{~cm}$ during 6 months). The patients in the Dutch study also had less pronounced blood pressure- and cholesterol reduction compared to our intervention group.

The patients in our study had positive attitude towards home visits by medical students. The students themselves considered the program as feasible. Therefore, we think that the program should be considered for testing in larger samples and in other settings with the further going aim to be implemented in rehabilitation of AMI patients. Given that the risk factors for cerebrovascular and other diseases associated with atherosclerosis including diseases of peripheral arteries are similar, our intervention program can be extended to other groups of patients after well-planned trials. 
The model of public health rehabilitation with medical assistants (physician assistants) being the main workforce can be effective not only for cardiovascular patients, but also for patients with malignant neoplasms, diabetes mellitus and chronic obstructive pulmonary disease [12, 18, 33]. Trained medical students can act as physician assistants in settings with limited resources. Our results clearly demonstrate that home visits to patients are effective in modifying risk factors. The program of educating medical assistants developed in Aktobe takes into account patients' behaviors and attitudes and emphasizes the importance of monitoring of blood pressure, blood lipids, body weight and other factors that contribute to cardiovascular and all cause mortality [26, 28, 32].

The main advantages of the study include its experimental design, novelty in recruiting medical students as physician assistants and practical importance of the findings. If replicated in other setting, the results may be used as an evidence for improvement of rehabilitation of AMI patients after discharge from the hospital. The CONSORT guidelines were followed in planning and implementing the study as well as the presentation of its results [16]. Detailed analysis of the differences in physical activity, mental health and the quality of life between the intervention- and the control group will be presented in our subsequent publications.

The results of the study should be interpreted and generalized taking into account some potential limitations. The average age of our patients was 57 years, which is younger than one may expect in other settings. The patients from the remote rural areas did not participate in the study due to transport limitations. Moreover, patients with severe co-morbidities were excluded that limits generalizability of our findings to the patients living in towns and with no severe co-morbidities. The patients were not blinded in relation to the intervention, therefore some placebo effect related to health-promoting factors associated with communications cannot be excluded. Although our findings should be interpreted with caution keeping in mind potential limitations of the study, they suggest that the program seems to be efficient to control risk factors and clearly demonstrates health benefits. Nevertheless, we recommend our study in other settings using large samples before the program is recommended for implementation in Kazakhstan.

\section{Conclusions}

Our results demonstrate that the program of public health rehabilitation of patients after AMI is effective in terms of risk factor management and compliance to treatment. The program seems to be well-accepted by the patients and is relatively easy to implement in other regions after replication of our study in other settings.

\section{Acknowledgements}

We thank all the patients who participated in the study. We also thank our colleagues from the Department of Cardiology who assisted in recruitment of the patients and Professor B. Zholdin for his advices and comments.
Damira G. Zhamankulova - ORCID 0000-0001-69430664; SPIN 1497-3260

Lazzat M. Zhamaliyeva - ORCID 0000-0003-3625-3651; SPIN 5887-4690

Ziyash Tanbetova - ORCID 0000-0003-1723-6848; SPIN 1303-3132

Gulnara L. Kurmanalina - ORCID 0000-0002-0937-2949; SPIN 8357-3777

Andrey M. Grjibovski - ORCID 0000-0002-5464-0498; SPIN 5118-0081

\section{References}

1. Ахмеджанов Н. М., Небиеридзе Д. В., Сарарян А. С., Выгодин В. А., Шураев А. Ю., Ткачева О. Н., Лишуma A. С. Анализ распространенности гиперхолестеринемии в условиях амбулаторной практики (по данным исследования АРГО): часть I // Рациональная фармакотерапия в кардиологии. 2015. № 11 (3). С. 253-260.

Akhmedzhanov N. M., Nebieridze D. V., Safaryan A. S., Vygodin V. A., Shuraev A. Yu., Tkacheva O. N., Lishuta A. S. Analysis of hypercholesterolemia prevalence in the outpatient practice (according to the ARGO study): Pt I. Ratsional'naya farmakoterapiya v kardiologii [Rational Pharmacotherapy in Cardiology]. 2015, 11 (3), pp. 253-260. [In Russian]

2. Бойцов С. А., Баланова Ю. А., Шальнова С. А. и $\partial p$. Артериальная гипертония среди лиц 25-64 лет: распространенность, осведомленность, лечение и контроль. По материалам исследования ЭССЕ // Кардиоваскулярная терапия и профилактика. 2014. № 14 (4). С. 4-14.

Boitsov S. A., Balanova Yu. A., Shal'nova S. A. et al. Arterial Hypertension among Individuals of 25-64 Years Old: Prevalence, Awareness, Treatment And Control. By the Data from ECCD. Kardiovaskulyarnaya terapiya $i$ profilaktika [Cardiovascular Therapy and Prevention]. 2014, 13 (4), pp. 4-14. [In Russian]

3. Европейские рекомендации по профилактике сердечно-сосудистых заболеваний в клинической практике (Пересмотр 2016) // Российский кардиологический журнал. 2017. T. 6 (146). C. $7-85$.

No authors listed. 2016 European Guidelines on Cardiovascular Disease Prevention in Clinical Practice. Rossiiskii kardiologicheskii zhurnal [Russian Journal of Cardiology]. 2017, 6 (146), pp. 7-85. [In Russian]

4. Недогода С. В., Сабанов А. В. Достижение целевого артериального давления у пациентов с артериальной гипертензией на фоне антигипертензивной терапии в условиях реальной клинической практики // Российский кардиологический журнал. 2018. Т. 23 (11). С. 100-109.

Nedogoda S. V., Sabanov A. V. Achievement of target blood pressure in patients with arterial hypertension on the background of antihypertensive therapy in real clinical practice. Rossiiskii kardiologicheskii zhurnal [Russian Journal of Cardiology]. 2018, 23 (11), pp. 100-109. [In Russian]

5. Рекомендации EOK/EOA по лечению дислипидемий // Рациональная фармакотерапия в кардиологии. 2012 Прил. № 1. С. 3-63.

ESC/EAS Guidelines for the management of dyslipidaemias: The Task Force for the management of dyslipidaemias of the European Society of Cardiology (ESC) and the European Atherosclerosis Society (EAS). Ratsional'naya farmakoterapiya v kardiologii [Rational Pharmacotherapy in Cardiology]. 2012, Suppl 1, pp. 3-63. [In Russian]

6. Садькова А. Д., Смаилова А. А., Шалапов Д. М., Саттиева С. К., Ауелбекова А. А. Эпидемиология основных фатальных осложнений сердечно-сосудистых заболеваний 
(обзор литературы) // Медицина (Алматы). 2017. № 11 (185). C. 61-66. [In Russian]

Sadykova A. D., Smailova A. A., Shalapov D. M., Sattieva S. K., Auelbekova A. A. Epidemiology of Main Fatal Complications of Cardiovascular Diseases (literature review). Meditsina (Almaty) [Medicina (Almaty)]. 2017, 11 (185), pp. 61-66.

Толпыгина С. Н., Полянская Ю. Н., Мариевич С. Ю. Гиполипидемическая терапия у пациентов с хронической ишемической болезнью сердца в 2004-2010 гг. по данным регистра «Прогноз ИБС» // Рациональная фармакотерапия в кардиологии. 2015. № 11 (2). С. 153-158.

7. Tolpygina S. N., Polyanskaya Yu. N., Martsevich S. Yu. Hypolipidemic Therapy in Patients with Chronic Ischemic Heart Disease in 2004-2010 According to the Prognoz IBS Register. Ratsional'naya farmakoterapiya v kardiologii [Rational Pharmacotherapy in Cardiology]. 2015, 11 (2), pp. 153-158. [In Russian]

8. Akyea RK, Kai J, Qureshi N, Iyen B, Weng SF. Suboptimal cholesterol response to initiation of statins and future risk of cardiovascular disease. Heart. 2019, 105 (13), pp. 975-981.

9. Allen JK, Dennison CR. Randomized trials of nursing interventions for secondary prevention in patients with coronary artery disease and heart failure: systematic review. $J$ Cardiovasc Nurs. 2010 May-Jun, 25 (3), pp. 207-20. DOI: 10.1097/ JCN.0b013e3181 cc79be. PMID: 20386243.

10. Aringazina A, Kuandikov T, Arkhipov V. Burden of the Cardiovascular Diseases in Central Asia. Cent Asian J Glob Health. 2018, 7 (1), p. 321.

11. Borghi C, Tubach F, De Backer G et al. Lack of control of hypertension in primary cardiovascular disease prevention in Europe Results from the EURIKA study. Int $J$ Cardiol. 2016, 218, pp. 83-88.

12. Bruinooge SS, Pickard TA, Vogel W et al. Understanding the role of advanced practice providers in oncology in the United States. JAAPA. 2018, 31 (12), pp. 1-12.

13. Chow CK, Jolly S, Rao-Melacini P, Fox KAA, Anand SS, Yusuf S. Association of diet, exercise, and smoking modification with risk of early cardiovascular events after acute coronary syndromes. Circulation. 2010, 121 (6), pp. 750-8.

14. Clark H. NCDs. A challenge to sustainable human development. Lancet. 2013, 381, pp. 510-511.

15. Czernichow S, Kengne AP, Stamatakis E, Hamer M, Batty GD. Body mass index, waist circumference and waist-hip ratio: which is the better discriminator of cardiovascular disease mortality risk?: evidence from an individual-participant metaanalysis of 82864 participants from nine cohort studies. Obes Rev. 2011, 12 (9), pp. 680-687.

16. Altman D, Schulz KF, Moher D et al. The Revised CONSORT Statement for Reporting Randomized Trials: Explanation and Elaboration. Academia and the Profession: 17 April 2001.

17. Finegold JA, Asaria P, Francis DP. Mortality from ischaemic heart disease by country, region, and age: statistics from World Health Organisation and United Nations. Int J Cardiol. 2013, 168 (2), pp. 934-45.

18. Garvey C, Ortiz G. Exacerbations of chronic obstructive pulmonary disease. Open Nurs J. 2012, 6, pp. 13-19.

19. Jayaraj JC, Davatyan K, Submanian SS Priya J. Epidemiology of Myocardial Infarction. DOI: 10.5772/ intechopen.74768.

20. Jorstad HT, von Birgelen C, Alings AM, et al. Effect of a nurse-coordinated prevention programme on cardiovascular risk after an acute coronary syndrome: main results of the RESPONSE randomised trial. Heart. 2013, 99 (19), pp. 1421-1430.

21. Kashkinbayeva AR, Tanbetova ZZh, Zhamaliyeva LM,
Zame YA, Zhamankulova DG. Motivational interview skills teaching in the training of PHC assistants in WKMU. West Kazakhstan Medical Journal. 2020, 62 (1), pp. 25-31.

22. Khan MAB, Hashim MJ, Mustafa H. et all. Global Epidemiology of Ischemic Heart Disease: Results from the Global Burden of Disease Study. Cureus. 2020 Jul 23, $12(7)$, e9349.

23. Kim C, Choi I, Cho S, Kim AR, Kim W, Jee S. Do Cardiac Rehabilitation Affect Clinical Prognoses Such as Recurrence, Readmission, Revascularization, and Mortality After AMI?: Systematic Review and Meta-Analysis. Ann Rehabil Med. 2021 Feb, 45 (1), pp. 57-70.

24. Kotseva K, De Backer G, De Bacquer D, et al. Lifestyle and impact on cardiovascular risk factor control in coronary patients across 27 countries: Results from the European Society of Cardiology ESC-EORP EUROASPIRE V registry. Eur J Prev Cardiol. 2019, 26 (8), pp. 824-835.

25. Lawler PR, Filion KB, Eisenberg MJ. Efficacy of exercise-based cardiac rehabilitation post-myocardial infarction: A systematic review and meta-analysis of randomized controlled trials. American Heart Journal. 2011 , 162 (4), pp. 571-584, e2.

26. Management of dyslipidaemia in patients with coronary heart disease:Results from the ESC-EORP EUROASPIRE V survey in 27 countries. Atherosclerosis. 2019, 285, pp. 135-146.

27. McMahon SR, Ades PA, Thompson PD. The role of cardiac rehabilitation in patients with heart disease. Trends Cardiovasc Med. 2017, 27 (6), pp. 420-425.

28. Nowbar AN, Gitto M, Howard JP, Francis DP, AlLamee R. Mortality from Ischemic Heart Disease. Circ Cardiovasc Qual Outcomes. 2019, 12 (6), e005375.

29. Piepoli MF. 2016 European Guidelines on cardiovascular disease prevention in clinical practice: The Sixth Joint Task Force of the European Society of Cardiology and Other Societies on Cardiovascular Disease Prevention in Clinical Practice (constituted by representatives of 10 societies and by invited experts). Int J Behav Med. 2017 Jun, 24 (3), pp. $321-419$.

30. Pivina LM, Moldagalieva ZhT, Muzdubayeva ZhE, Belikhina TI, Markabayeva AM, Zhunussova TT. Medical and social problem of cardiovascular diseases in Kazakhstan. Science \& Healthcare. 2015, 2.

31. Roth GA, Johnson C, Abajobir A, et al. Global, Regional, and National Burden of Cardiovascular Diseases for 10 Causes, 1990 to 2015. J Am Coll Cardiol. 2017, 70 (1), pp. 1-25.

32. Soo Hoo SY, Gallagher R, Elliott D. Predictors of cardiac rehabilitation attendance following primary percutaneous coronary intervention for ST-elevation myocardial infarction in Australia. Nurs Health Sci. 2016, 18 (2), pp. 230-7.

33. Virani SS, Maddox TM, Chan PS et al. Provider Type and Quality of Outpatient Cardiovascular Disease Care: Insights From the NCDR PINNACLE Registry. $\mathrm{J}$ Am Coll Cardiol. 2015, 66 (16), pp. 1803-1812.

34. Urbinati S, Tonet E. Cardiac rehabilitation after STEMI. Minerva Cardioangiol. 2018, 66 (4), pp. 464-470.

35. 2018 ESC/ESH Guidelines for the Management of Arterial Hypertension. Eur Heart J. 2018, 40 (25), p. 2092.

\section{Contact details:}

Damira Zhamankulova - PhD student at the West Kazakhstan Marat Ospanov Medical University, Aktobe, Kazakhstan 68 Maresyev St., Aktobe 030019

E-mail: bianconeri-98@mail.ru 